\title{
TINJAUAN YURIDIS PERBANDINGAN SISTEM PILKADA LANGSUNG DAN TIDAK LANGSUNG BERDASARKAN DEMOKRASI PANCASILA
}

\author{
Drs.Wawan S.,MM, Yudhitiya D.S.,SH,MH, Gaya Caecia,SH,MH \\ Fakultas Ekonomi Universitas Semarang
}

\begin{abstract}
Abstrak
Sistem pemerintahan di Indonesia tidak terlepas dari peran pemerintah daerah. Adapun sistem pemilukada (pemilihan umum kepala daerah) yang pernah diterapkan di Indonesia meliputi pemilihan secara langsung dan tidak langsung. Mayoritas masyarakat Indonesia cenderung pro terhadap sistem pemilhan secara langsung dan kontra terhadap pemilihan secara tidak langsung. Rumusan masalah dalam penelitian ini, yaitu pertama apakah sistem pilkada tidak langsung bertentangan atau tidak dengan sistem demokrasi pancasila, dan rumusan masalah yang kedua bagaimanakah perbandingan sistem pilakada langsung dan sistem pemilukada tidak langsung ditinjau berdasarkan demokrasi Pancasila. Metode penelitian yang digunakan oleh Penulis adalah metode pendekatan yuridis normatif. Berdasarkan hasil penelitian dan pembahasan, Penulis menyimpulkan, pertama, pada dasarnya, pilkada dengan sistem pemilihan tidak langsung, tidak bertentangan dengan Dasar Negara dan Konstitusi Negara Kesatuan Republik Indonesia..Kesimpulan kedua, Mekanisme pemilukada dengan menggunakan sistem secara langsung dan secara tidak langsung, jika dibandingkan, cenderung lebih menguntungkan dengan menggunakan sistem pemilihan secara tidak langsung.
\end{abstract}

Kata Kunci : Pemerintah Daerah, Pemilukada, Demokrasi Pancasila

\begin{abstract}
Government system in Indonesia can not be separated from the role of local governments. The system of election (elections of regional heads) that had been applied in Indonesia include the election directly and indirectly. The majority of Indonesian people tend to be pro against direct election system and against indirect election. The problems of this study, namely first whether the election system does not directly contradict or not with a democratic system of Pancasila, and the formulation of the second how the system comparison election of direct and indirect election system be reviewed based on Pancasila democracy. The method used by the author is a normative juridical approach. Based on the results of research and analysis, Author concluded, first, in essence, the election system of indirect election, does not conflict with the Constitution of the State and the Constitution of the Republic Indonesia. Second conclution, the election mechanism using the system directly and indirectly, if in comparison, tend to be more profitable by using a system of indirect election.
\end{abstract}

Keywords: Local Government, Election, Democracy Pancasila

\section{PENDAHULUAN}

Latar belakang

Sistem pemerintahan di Indonesia tidak terlepas dari peran pemerintahan daerah, dimana pemerintahan daerah dan struktur pemerintahan meliputi Gubernur, Bupati dan Walikota didapatkan melalui pemilukada atau pemilihan umum kepala daerah. Dewasa ini muncul berbagai macam pembahasan mengenai pemilihan 
kepala daerah yang kemudian memunculkan polemik dan permasalahan dengan disahkan nya UU No.22 tahun 2014 Tentang Pemilihan Gubernur,Bupati dan Walikota. Perjalanan pemilukada sejak era kemerdekaan hingga era reformasi seperti sekarang ini sering berganti mekanisme pemilihan. Mulai mekanisme pemilihan langsung hingga mekanisme pemilihan secara tidak langsung.Hingga puncaknya pada saat disahkan UU No.22 Tahun 2014, polemik yang muncul adalah masyarakat cenderung kontra terhadap Undang-Undang tersebut, karena mekanisme pemilihan secara tidak langsung dianggap bertentangan dengan Pancasila dan Konstitusi. Disisi lain, pemerintah justru segera mengeluarkan Perppu No.1 Tahun 2014 untuk membatalkan UU No.22 Tahun 2014.Otomatis, mekanisme pemilukada yang diberlakukan secara tidak langsung berganti kembali dengan menggunakan sistem pemilihan secara langsung. Berdasarkan penggantian kebijakan tersebut, Penulis ingin mengkaji, apakah ada yang salah dengan pemilukada menggunakan sistem pemilihan secara tidak langsung?

\section{Rumusan Masalah}

Berdasarkan latar belakang masalah yang telah dikemukakan diatas, penulis merumuskan permasalahan yang akan dibahas dalam penelitian ini adalah sebagai berikut:

1. Apakah sistem pilkada tidak langsung bertentangan dengan sistem demokrasi pancasila?

2. Bagaimanakah perbandingan sistem pilakada langsung dan sistem pilkada tidak langsung ditinjau berdasarkan demokrasi Pancasila?

\section{Tujuan Penelitian}

Berdasarkan uraian latar belakang dan rumusan masalah tersebut di atas, adapun tujuan dari penelitian ini yaitu:
1. Untuk mengetahui dimana pelanggaran demokrasi pancasila dalam pemilihan pilkada secara tidak langsung.

2. Untuk mengetahui perbandingan yang mendasar antara pilkada langsung dan tidak langsung dalam sistem demokrasi Pancasila.

\section{Manfaat Penelitian}

Hasil penelitian dan penulisan ini diharapkan dapat bermanfaat baik secara teoritis maupun secara praktis.Manfaat Teoritis, yaitu pertama, hasil penelitian ini diharapkan dapat memberi kontribusi terhadap perkembangan atau terobosan baru dalam sistem pemilihan umum terutama pemilihan kepala daerah di Negara Indonesia dengan sepenuhnya mengacu pada demokrasi Pancasila baik dilaksanakan melaui pilkada langsung maupun pilkada tidak langsung. Kedua, Penelitian ini diharapkan dapat melengkapi bahan bahan penelitian dan menjadi acuan penyelesaian pro dan kontra sistem pemilihan pilkada tidak langsung serta pertimbangan untuk memperbaharui Perppu nomor 1 tahun 2014. Manfaat Praktis yaitu, pertama penelitian ini diharapkan dapat menambah gagasan dalam berpikir bagi masyarakat,akademisi dan pembuat undang-undang dalam upaya penyempurnaan penerbitan undangundang yang mengatur tentang pemilihan umum ataupun pemilihan kepala daerah agar tidak menimbulkan polemik bagi bangsa Indonesia. Kedua, penelitian ini diharapkan mampu memberikan sumbangsih gagasan terhadap para pembuat undang-undang dan masyarakat agar melihat suatu permasalahan dari segi yuridis serta memahami betul arti dari demokrasi Pancasila 


\section{KAJIAN PUSTAKA}

\section{Tinjauan Yuridis Pemilihan Umum Kepala Daerah}

a. Definisi Pimpinan Daerah

Pengertian pimpinan daerah bertumpu pada pengertian yang diberikan secara yuridis dalam hubungannya dengan Pasal 18 UUD 1945 yang menyebutkan bahwa gubernur, bupati, walikota masing-masing sebagai kepala pemerintahan provinsi, kabupaten, dan kota yang dipilih secara demokratis. Selain itu UU No. 32 Tahun 2004 selaku aturan yang melaksanakan amanah UUD NRI Tahun 1945 yang diatur dalam Pasal 18ayat (4)diatas, dalam Pasal 24 ayat (1) menyatakan setiap daerah dipimpin oleh kepala pemerintahan daerah yang disebut kepala daerah. Di samping itu, Pasal 24 ayat (2) UU No. 32 Tahun 2004 tentang Pemerintahan Daerah menyebutkan bahwa kepala daerah sebagaimana dimaksud ayat (1) untuk provinsi disebut gubernur, untuk kabupaten disebut bupati, dan untuk kota disebut walikota. Selanjutnya dalam menentukan tugas dan wewenang kepala daerah yaitu gubernur, bupati, dan walikota, oleh UU No, 32 Tahun 2004, dalam Pasal 25 mengatur bahwa kepala daerah memiliki tugas dan wewenang memimpin penyelenggaraan pemerintahan daerah berdasarkan kebijakan yang ditetapkan bersama DPRD. Dalam Pasal 21 UU No. 32 Tahun 2004 mengatur hak dan kewajiban daerah dalam menyelenggarakan otonomi daerah memakai kata pimpinan dalam ayat (6) yang menyatakan memilih pimpinan daerah.

\section{b. Sistem Pemilihan Kepala Daerah}

Pemilihan Kepala Daerah Tidak Langsung

Pada Pasal 18 ayat (4) UUD 1945 menyatakan gubernur, bupati dan walikota dipilih secara langsung melalui pemilihan. Dalam Pembukaan Alinea Keempat UUD NR! Tahun 1945 sebagai salah satu acuan berdemokrasi di Indonesia menyatakan bahwa 'kemudian dari pada itu untuk membentuk suatu pemerintahan negara Indonesia yang melindungi segenap bangsa Indonesia dan seluruh tumpah darah Indonesia dan untuk memajukan kesejahteraan umum mencerdaskan kehidupan bangsa dan ikut melaksanakan ketertiban dunia yang berdasarkan kemerdekaan perdamaian abadi dan keadilan sosial maka disusunlah kemerdekaan kebangsaan Indonesia itu dalam suatu UUD 1945 yang berkedaulatan rakyat dengan berdasar kepada Ketuhanan Yang Maha Esa, kemanusiaan yang adil dan beradab, persatuan Indonesia, kerakyatan yang dipimpin oleh hikmah dan kebijaksanaan dalam permusyawaratan dan perwakilan dan keadilan sosial bagi seluruh rakyat Indonesia.

Penekanan Pembukaan UUD 1945 pada kedaulatan rakyat memberikan salah satu arti bahwa Indonesia adalah negara demokrasi, oleh karena itu sistem yang ada dalam pemerintahan maupun kehidupan bernegara haruslah dijiwai oleh kedaulatan rakyat atau demokrasi dan karenanya pasal-pasal yang terdapat dalam UUD NRI Tahun 1945 bemafaskan kedaulatan rakyat atau demokrasi yang tercermin dalam Pasal 1 ayat (2) yang menyatakan kedaulatan berada di tangan rakyat dan dilaksanakan menurut UUD. Dalam pelaksanaan pemerintahan negara, kedaulatan rakyat merupakan sesuatu yang sakral dan tidak dapat ditawar-tawar yang tercermin dalam Pasal 7 UUD NRI Tahun 1945 yang menyatakan presiden tidak dapat memberhentikan dan atau membubarkan DPR. Hal ini menunjukkan betapa rakyat dihargai dalam negara demokrasi sebab presiden selaku pemegang kekuasaan pemerintahan tidak dapat menganggu gugat DPR.

Suatu hal yang sudah dipahami bahwa UUD di hampir semua negara mengatur hal-hal yang disebutkan di atas yang merupakan aturan pokok tertulis yang 
dimaksudkan untuk mencapai kesatuan hukum kesederhanaan hukum dan tentunya kepastian hukum. Demikian juga dengan UUD Negara Kesatuan Republik Indonesia Tahun 1945 yang mengatur antara lain tentang pemerintahan negara termasuk didalamnya tentang pemerintahan daerah dan lain-lain yang hanya merupakan aturan pokok saja dimaksudkan agar mencapai kesatuan hukum, kesederhanaan hukum dan kepastian hokum. PadaEra Orde Baru berdasarkan UU nomor 5 tahun 1974, pilkada tidak dapat dilepaskan dari keterlibatan elit politik di pusat atau lingkaran kekuasaan Presiden. Menurut UU Nomor 5 Tahun Kepala daerah dipilih dan dicalonkan oleh DPRD, hasil pemilihan lalu diajukan kepada pemerintah untuk diangkat. Pengangkatan kepala daerah oleh pemerintah tidak terikat oleh pemilihan yang dilakukan oleh DPRD, dalam hal ini DPRD selaku pelaksana keinginan pemerintah pusat.

Setelah reformasi bergulir, berdasarkan UU No.22 Tahun 1999, pilkada dilakukan menggunakan sistem pemilihan demokrasi tidak langsung dimana kepala daerah dan wakil kepala daerah dipilih oleh DPRD dengan penegasan asas desetralisasi yang kuat. Dengan begini posisi serta peran politik DPRD sama dengan kepala daerah.Berdasarkan UU Nomor 22 Tahun 1999, pilkada dilakukan dengan sistem pilkada tidak langsung dalam banyak praktik pemilihan kepala daerah dengan sistem seperti ini tidak mampu menyerap aspirasi masyarakat secara optimal,banyak ditemukan seperti kevenderungan oligarki partai politik yang menyebabkan politisasi aspirasi publik.Di samping rawan politik uang pemilhan dengan sistem demokrasi tidak langsung sering kali menghasilkan kepala daerah yang tidak popular dan tidak mengenal karate dan potensi khas daerah, calon yang diajukan tidak dikenal secara luas oleh masyarakat. Dari hal demikian maka timbul konflik kekerasan secara vertikal dan horizontal.

Pemilihan Kepala Daerah Secara Langsung

Pemilukada sebagaimana diatur dalam UU No. 32 Tahun 2004 semula memberikan harapan tumbuh suburnya demokrasi dan terpilihnya kepala daerah baik provinsi dan kabupaten/kota yang mendapat dukungan luas dari rakyat. Namun setelah berjalan beberapa kali timbulah hal-hal yang kurang diinginkan. Karena penyelenggaraan Pemilukada di setiap daerah yang dilaksanakan oleh KPUD menghabiskan anggaran negara dan daerah yang cukup banyak. Di samping para calon pimpinan daerah dalam proses pemilihan setelah terpilih menjadi kepala daerah menanggung utang yang sangat banyak, juga dari segi keamanan dan keharmonisan hubungan selama terjadinya proses pemilihan pimpinan daerah sering terganggu yang kadang-kadang menimbulkan korban yang tidak perlu akibat keterlibatan massa yang emosional.

Beberapa pertimbangan yang melandasi pilkada langsung adalah pertama, Sistem pemerintahan sesuai UUD 1945 memberikan keleluasaan kepada daerah untuk menyelenggarakan otonomi daerah. Kedua, dalam menyelenggarakan otonomi daerah perlu ditekankan prinsip-prinsip demokrasi. Ketiga, dalam rangka pengembangan kehidupan demokrasi, keadilan, pemerataan, kesejahteraan rakyat, hubungan yang serasi antara pemerintah pusat dan daerah serta antar daerah unuk menjaga keutuhan NKRI, Kedudukan kepala daerah mempunyai peran yang sangat strategis.

Pilkada langsung merupakan perubahan penting dalam proses konsolidasi demokrasi, pilkada langsung dipandang memiliki jumlah keunggulan dibanding dengan sistem recruitment 
politik melalui institusi DPRD. Ada beberapa kondisi yang mendorong pilkada dilakukan secara langsung, pilkada langsung menawarkan sejumlah manfaat dan sekaligus harapan bagi pertumbuhan, pendalaman dan perluasan demokrasi lokal. Pilkada langsung adalah suatu mekanisme yang sangat demokratis berbeda dengan sebelumnya. Pemilihan kepala daerah pada saat berlakuanya UU No. 5 Tahun 1974 dan Undang-Undang No. 22 Tahun 1999 rakyat tidak terlibat langsung dalam menentukan kepala daerah dan wakil kepala daerah, sehingga terkadang yang menjadi kepala daerah hanya merupakan representasi dari partai politik, elit politik lokal dan pemerintah pusat. Dengan sistem keterwakilan atau pemilahan kepala daerah tidak langsung yang men-jadi kepala daerah terkadang perilakunya tidak berpihak pada rakyat dan lebih berpihak pada partai atau kualisi partai, elit yang mengusungnya.Dengan adanya Pilkada secara langsung membuka peluang rakyat untuk menyeleksi sendiri terhadap calon kepala daerah dan wakil kepala daerah yang dikehendaki rakyat.

\section{Sistem Demokrasi Pancasila}

\section{a. Definisi Demokrasi}

Secara etimologis "demokrasi" terdiri dari dua kata Yunani yaitu "demos" yang berarti rakyat atau penduduk suatu tempat dan "cratein"atau "cratos" yang berarti kekuasaan dan kedaulatan. Gabungan dua kata demos-cratein atau demos-cratos (demokrasi) memiliki arti suatu keadaan negara di mana dalam sistem pemerintahannya kedaulatan berada di tangan rakyat, kekuasaan tertinggi berada dalam keputusan bersama rakyat, rakyat berkuasa, pemerintahan rakyat, dan kekuasaan oleh rakyat. Sedangkan pengertian demokrasi menurut istilah atau terminologi adalah seperti yang dinyatakan oleh para ahli sebagai berikut:
- Joseph A. Schemer mengatakan demokrasi merupakan suatu perencanaan institusional untuk mencapai keputusan politik di mana individuindividu memperoleh kekuasaan untuk memutuskan cara perjuangan kompetitif atas suara rakyat;

- Sidney Hook berpendapat demokrasi adalah bentuk pemerintahan di mana keputusan-keputusan pemerintah yang penting secara langsung atau tidak langsung didasarkan pada kesepakatan mayoritas yang diberikan secara bebas oleh rakyat biasa.

- Philippe C. Schmitter dan Terry Lynn Karl menyatakan demokrasi sebagai suatu sistem pemerintahan dimintai tanggung jawab atas tindakantindakan mereka yang telah terpilih.

Menurut Lincoln, demokrasi adalah suatu bentuk pemerintahan di mana kekuasaan politik tertinggi (supreme political authority) dan kedaulatan (sovereignty)ada di tangan rakyat. Rakyat yang memiliki "sovereignty"berhak untuk memerintah. Karena itu, pemerintahan yang demokratis adalah pemerintahan yang mendapat persetujuan rakyat atau pemerintahan yang sudah memiliki mandat untuk memerintah dari rakyat (democratic government by and with the consent of the people).Dalam sistem pemerintahan rakyat atau yang oleh Lincoln disebut "government by people" tersebut direpresentasi dalam bentuk lembaga perwakilan yang mengatasnamakan kepentingan rakyat.

b. Definisi Demokrasi Pancasila

Demokrasi Pancasila tidak saja demokrasi dalam bidang politik, yang hanya mengatur tentang masalah politik negara atau hal yang berhubungan dengan penantian kenegaraan, tetapi juga mengatur masalah ekonomi, sosial, dan kebudayaan. Pengaturan pokok masalah itu terdapat di dalam UUD 1945. Peng- aturan itu dapat dlihat dalam Pasal 
31 mengenai pendidikan, Pasal 32 mengenai kebudayaan, Pasal 33 mengenai perekonomian, Pasal 34 mengenai fakir miskin.

Dengan perkataan lain dapat dikatakan bahwa demokrasi Pancasila adalah demokrasi politik, demokrasi ekonomi, sosial dan kebudayaan. Dalam hal ini berarti bahwa dalam bidang politik, ekonomi, sosiali dan kebudayaan, rakyat diikut sertakan dalam keterlihatannya sehingga masalah itu dirasakan sebagii ma- salahnya dengan demikian, gagasan demokrasi sebagai suatu perkembangan "populisme" (ketertiban atau ikut campur tanpa rakyat) diatur sccara konstitusional. Konstilusional, yang dalam hal ini UUD 1945, telah meletakkan lipris-garis pokok kegiatan itu. Secara keseluruhan dapat disimpulkan bahwa demokrasi Pancasila mencakup macam-macam demokrasi. Di samping sebagai demo- krasi politik, ekonomi, sosial, dan kebudayaan, juga sebagai demokrasi konstitusional sebab demokrasi ini berdasar atas konsti- tusi, yaitu UUD 1945. UUD itu sendiri merupakan realisasi Pancasila sebagai dasar negara.

Di samping sebagai suatu sistem pemerintahan, demokrasi juga merupakan Way of life atau tara hidup dalam bidang pemerintah. Demokrasi sebagai suatu cara hidup yang bayak antara lain meliputi halhal scbagai bcrikut. Pertama, Segala pendapat atau perbedaan pendapat mengenai msalah kenegaraan dan lain-lain yang menyangkut kehidupan bangsa dan masyarakat diselesaikan lewat lembagalembaga negara. Kedua, diskusi, Sebagai suatu negara demokrasi, di mana rakyat diikursertakan dalam masalah negara, maka pertukaran pikiran yang bebas demi terselenggaranya kepentingan rakyat, maka diskusi harus dibuka seluas-luasnya.

Di bawah demokrasi Parcasila Indonesia dapat merasakan stabilitas Nasional yang cukup memadai. Keamanan terkendali sektor ekonomi maju pesat pembangunan diupayakan dapat merata ke pelosok-pelosok negeri, meskipun hanya sedikit yang berhasil. Target dari sistem Demokrasi Pancasila adalah pem- bangunan ekonomi yang berencana, untuk kesejahteraan rakyat, karena stabilitas politik dan keamanan menjadi persoalan bangsa yang amat penting.

\section{METODE PENELITIAN Metode Pendekatan}

Metode pendekatan yang digunakan adalah yuridis normatif. Aspek yuridis dalam penelitian ini melengkapi ilmu hukum tata negara dan dimulai dengan mengkaji peraturan perundang-undangan yang berkaitan dengan penelitian, yaitu Undang-Undang Dasar Republik Indonesia Tahun 1945, UU No.32 Tahun 2004 Tentang Pemerintahan Daerah, UU No.22 Tahun 2014 Tentang Pemilihan Gubernur, Bupati , Walikota, Perppu No.1 Tahun 2014 Tenta Pemilihan Gubernur, Bupati, Walikota. Aspek normatif pada penelitian ini didasarkan pada data sekunder yang relevan dengan penelitian meliputi bahan-bahan kepustakaan yang berkaitan dengan ilmu hukum tata negara, khususnya mengenai hukum otonomi daerah.

\section{Spesifikasi Penelitian}

Spesifikasi yang digunakan bersifat deskriptif analitis, yaitu dalam penulisan hukum ini memaparkan, melukiskan atau menggambarkan suatu peraturan perundang-undangan yang berlaku yaitu UU No.32 Tahun 2004 Tentang Pemerintahan Daerah dan peraturan perundang-undangan lainnya yang berkaitan. Dikaitkan dengan teori-teori hukum dan praktek yang menyangkut objek masalah yang diteliti, yaitu masalah pelaksanaan sistem pemilukada.

Metode Pengumpulan Data 
Data yang dikumpulkan dalam penelitian ini merupakan data sekunder dan pengkajiannya dilengkapi pula dengan data-data lapangan maupun penelitian sebagai data pendukung. Dalam penelitian ini, data sekunder yang dimaksud adalah dokumen-dokumen pelaksanaan pemilukada dengan sistem pemilihan langsung dan sistem pemilihan tidak langsung. Sedangkan data-data lapangan sebagai data pendukung diperoleh dari observasi, wawancara, maupun keterangan atau informasi dari narasumber yang relevan. Pengumpulan data sekunder dalam penelitian ini dilakukan melalui studi kepustakaan, yang meliputi bahan hukum primer, bahan hukum sekunder dan bahan hukum tersier.

\section{Metode Analisa Data}

Proses analisis dalam penelitian ini akan dimulai dengan cara mengumpulkan semua data, selanjutnya, terhadap datadata tersebut dilakukan proses editing dan diintepretasi untuk kemudian dianalisis. Analisis terhadap data dilakukan secara bertahap sehingga data yang kurang dapat diketahui dan dilengkapi dengan pengambilan data tambahan. Metode analisis data menggunakan analisis data kualitatif dengan metode penarikan kesimpulan adalah berpikir deduktif, yaitu metode berpikir yang mendasarkan pada hal-hal yang bersifat umum untuk kemudian ditarik kesimpulan menuju penulisan yang bersifat khusus.

\section{HASIL PENELITIAN DAN PEMBAHASAN}

a. Sistem Pilkada Tidak Langsung Ditinjau Berdasarkan Demokrasi Pancasila

Rezim pemilu di dalam UUD NKRI Tahun 1945 Pasal 22E ayat (2) hanya ada 4 jenis pemilu, yaitu pemilu untuk memilih anggota DPR, pemilu untuk memilih anggota DPD, pemilu untuk memilih anggota DPRD, dan pemilu untuk memilih presiden dan wakil presiden. Pilkada menurut UndangUndang Dasar 1945 tidak termasuk rezim pemilihan umum. Disisi lain, jika otonomi diberikan kepada Propinsi, maka pemilihan bupati dan walikota dapat diserahkan kepada DPRD. Apabila merujuk pada Pasal 18 UUD NKRI Tahun 1945, dikatakan, Gubernur-Wakil gubernur, Bupati-Wakil Bupati, Walikota-Wakil Walikota dapat dipilih dengan cara demokratis. Demokratis dapat diartikan secara langsung dan dapat diartikan secara tidak langsung.

Terkait dengan pemilihan kepala daerah, pemilihan kepala daerah ini terdapat dalam amandemen UUD NKRI Tahun 1945 Pasal 18. Pasal 18 hanya menyatakan bahwa Gubernur, Bupati dan walikota dipilih melalui cara-cara yang "demokratis". Cara-cara yang demokratis bermakna multitafsir, tergantung bagaimana UU menterjemahkannya. Pada awalnya, pemilihan dilakukan dengan mekanisme keterwakilan oleh DPRD dan saat ini sistem pemilihan berganti kembali secara langsung oleh rakyat. Pada dasarnya kedua sistem pemilukada tersebut sama-sama tidak bertentangan dengan Dasar Negara dan Konstitusi. Apabila pilkada dilakukan secara langsung, maka demokrasi yang digunakan adalah demokrasi secara murni, dimana pelaksanaan pilkada dilakukan oleh rakyat, dari rakyat dan untuk rakyat berdasarkan nilai-nilai Dasar Negara Indonesia yaitu Pancasila. Disisi lain, sistem pilkada secara tidak langsung juga merupakan perwujudan dari pelaksanaan demokrasi Pancasila. Perbedaannya, demokrasi yang diterapkan adalah demokrasi keterwakilan, dimana pemilihan kepala daerah dilakukan oleh anggota DPRD setempat. Anggota DPRD disini juga merupakan perwujudan rakyat Indonesia. Dengan demikian, pemilihan secara tidak langsung tidak bertentangan dengan demokrasi Pancasila, sebagaimana 
tercermin dalam sila keempat "kerakyatan yang dipimpin oleh hikmat dalam permusyawaratan perwakilan".

\section{b. Perbandingan Sistem Pilkada}

Langsung dan Sistem Pilkada Tidak

Langsung Berdasarkan Demokrasi

Pancasila

Semangat dilaksanakannya pilkada langsung adalah koreksi terhadap sistem demokrasi tidak langsung di era sebelumnya, dimana kepala daerah dan wakil kepala daerah dipilh oleh DPRD, menjadi demokrasi yang berakar langsung pada pilihan rakyat.Oleh karena itu keputusan politik untuk menyelenggarakan pilkada langsung adalah langkah strategis dalam rangka memperluas,memperdalam dan meningkatkan kualitas demokrasi. Hal ini juga sejalan dengan semangat otonomi yaitu pengakuan terhadap aspirasi inisiatif masyarakat local untuk menentukan nasibnya sendiri. Jika agenda desentralisasi dilihat dalam kerangka besar demokratisasi kehidupan bangsa, maka pilkada semestinya memberikan kontribusi yang besar terhadap hal itu. Berikut hasil perbandingan mengenai sisi positif pilkada secara langsung dan dibandingkan dengan sistem pilkada secara tidak langsung.

Tabel 1. Perbadingan Sistem Pilkada Langsung dan Tidak Langsung

\begin{tabular}{|c|c|}
\hline Pilkada Langsung & Pilkada Tidak Langsung \\
\hline $\begin{array}{l}\text { Pilkada langsung merupakan } \\
\text { perwujudan kedaulatan rakyat dan } \\
\text { demokrasi seluas-luasnya. Sebagai- } \\
\text { mana pemeo demokrasi: "dari rakyat, } \\
\text { oleh rakyat, untuk rakyat" maka } \\
\text { sebagai rakyat kita sangat berhak } \\
\text { untuk menentukan siapa yang akan } \\
\text { memimpin kita, siapa yang berhak } \\
\text { mengelola uang pajak yang kita } \\
\text { bayar, dan kepada siapa kita mem- } \\
\text { percayakan pembangunan daerah } \\
\text { kita dalam jangka waktu lima tahun } \\
\text { ke depan. }\end{array}$ & $\begin{array}{l}\text { Apakah kedaulatan rakyat harus sampai level } \\
\text { memilih pemimpin daerah? } \\
\text { Apakah kedaulatan rakyat tidak cukup } \\
\text { diwakilkan ke wakil rakyat (DPRD) ? Bukankah } \\
\text { DPRD juga dipilih oleh rakyat untuk } \\
\text { mewakilinya? } \\
\text { Apakah perwujudan kedaulatan rakyat tersebut } \\
\text { merupakan perwujudan sesungguhnya? } \\
\text { Berapa banyak jumlah warga daerah yang } \\
\text { berpartisipasi memilih pemimpin daerah? } \\
\text { Berapa banyak rakyat yang justru tidak merasa } \\
\text { perlu untuk memilih Bupati/Walikota/Gubernur } \\
\text { sehingga memutuskan golput? } \\
\text { Apabila benar kedaulatan rakyat ini mau } \\
\text { diwujudkan dengan seluas-luasnya, apakah } \\
\text { rakyat mengetahui siapa calon kepala daerah dan } \\
\text { bagaimana kualitasnya? }\end{array}$ \\
\hline
\end{tabular}




\begin{tabular}{|c|c|}
\hline Pilkada Langsung & Pilkada Tidak Langsung \\
\hline $\begin{array}{l}\text { Pilkada langsung } r \text { merupakan } \\
\text { pengejawantahan dari } r \text { tuntutan } \\
\text { reformasi dan demokratisasi politik } \\
\text { serta merupakan hak konstitusi } \\
\text { rakyat. }\end{array}$ & $\begin{array}{l}\text { Bukankah dasar Negara kita (Sila keempat } \\
\text { Pancasila) menyaratkan pemerintahan } \\
\text { demokratis harus didasarkan asas keterwakilan? }\end{array}$ \\
\hline & $\begin{array}{l}\text { Bukankah UUD } 1945 \text { hanya menyebutkan } \\
\text { presiden, DPR, DPRD, dan DPD yang langsung } \\
\text { dipilih oleh rakyat melalui pemilihan umum, } \\
\text { sama sekali tidak menyebutkan Bupati / } \\
\text { Walikota / Gubernur dipilih lewat pemilu? }\end{array}$ \\
\hline $\begin{array}{l}\text { Menghindari terjadinya persekong- } \\
\text { kolan politik Kepala Daerah dengan } \\
\text { DPRD. }\end{array}$ & $\begin{array}{l}\text { Apakah apabila Kepala Daerah dipilih langsung } \\
\text { dijamin tidak ada persekongkolan politik antara } \\
\text { Kepala Daerah dengan DPRD? } \\
\text { Apakah selama ini tidak ada kasus korupsi yang } \\
\text { melibatkan Kepala Daerah yang dipilih langsung } \\
\text { dengan oknum-oknum DPRD? } \\
\text { Bukankah politik uang masalahnya ada di } \\
\text { perilaku saja? Apabila anggota DPRD jujur } \\
\text { maka politik uang dapat dihindarkan? }\end{array}$ \\
\hline $\begin{array}{l}\text { Meminimalisasi politik uang Kepala } \\
\text { Daerah kepada DPRD, baik selama } \\
\text { masih jadi calon maupun setelah } \\
\text { menjabat. }\end{array}$ & $\begin{array}{l}\text { Apakah selama ini semua kandidat Bupati/ } \\
\text { Walikota/Gubernur yang akan dipilih langsung } \\
\text { sama sekali tidak melakukan politik uang kepada } \\
\text { DPRD? }\end{array}$ \\
\hline $\begin{array}{l}\text { Pilkada secara langsung disertai } \\
\text { dengan pengawasan oleh lembaga } \\
\text { yang berwenang. }\end{array}$ & $\begin{array}{l}\text { Apakah pengawasan dapat dilakukan secara } \\
\text { efektif? }\end{array}$ \\
\hline
\end{tabular}

\section{SIMPULAN}

Berdasarkan hasil penelitian dan pembahasan, maka Penulis menyimpulkan sebagai berikut :

a. Pada dasarnya, pilkada dengan sistem pemilihan tidak langsung, tidak bertentangan dengan Dasar Negara dan Konstitusi Negara Kesatuan Republik Indonesia. Inti dari demokrasi pancasila adalah pemerintahan yang dilaksanakan dari rakyat, oleh rakyat dan untuk rakyat dengan berlandaskan nilai-nilai Pancasila, sehingga dapat disimpulkan, meskipun pemilihan dilakukan secara tidak langsung melalui anggota DPRD, namun anggota DPRD juga merupakan simbol keterwakilan masyarakat sebagai pemilih. Artinya, sama-sama dipilih oleh rakyat.

b. Mekanisme pemilukada dengan menggunakan sistem secara langsung dan secara tidak langsung, jika dibandingkan, cenderung lebih menguntungkan dengan menggunakan sistem pemilihan secara tidak 
langsung. Berbagai sisi positif tersebut yaitu, menghemat biaya APBD dan APBN hingga triliunan rupiah, Menjalankan amanah Konstitusi. Dasar Negara kita, tepatnya Sila keempat Pancasila secara terang benderang mengatakan bahwa "Kerakyatan yang dipimpin oleh hikmah kebijaksanaan dalam permusyawaratan perwakilan".

\section{DAFTAR PUSTAKA}

\section{$\underline{\text { Buku }}$}

Adi,Rianto,2004. “Metodologi Penelitian Sosial dan Hukum”,Jakarta: Granit

Soebijanto,FX,1998.“Perencanaan Riset dan Strateginya: Kursus Penyegaran Metode Penelitian Bagi DosenDosen “, Semarang: Undip Press

Asshiddiqie, Jimly,2202."Konsolidasi Naskah UUD 1945 Setelah Perubahan Keempat”, Jakarta: Pusat Studi Hukum Tata Negara UI

Aswata,I Gede Pantja,2008.'Problematika Hukum Otonomi Daerah di Indonesia",Bandung:Alumni,2008

Ashofa,Burhan, 1996." Metode Penelitian Hukum”, Jakarta: Rineka Cipta

Bagus,Lorens,2002."Kamus Filsafat" ,Jakarta: Gramedia Pustaka Utama

Sumitro,Ronny Hanitijo,1990.“ Metode Penelitian Hukum dan Jumitri”, Jakarta: Ghalia Indonesia

Kaelan, 2010.Pendidikan Pancasila, Yogyakarta: Paradigma

Sahdan,Gregorius, 2004.“ Jalan Transisi Demokrasi: Pasca Soeharto", Yogyakarta: Pondok Edukasi
Suharizal,2012. "Pemilukada

Regulasi,Dinamika dan Konsep

Mendatang”, Jakarta:PT.Raja

Grafindo Persada,2012

Suryatmaja M,2003."Pemilihan Kepala Daerah Langsung,dimuat dalam Roundtable Discussion diterbitkan oleh Yayasan Inovasi Pemerintah Daerah (Center for Local Goverment Innovation), Jakarta

Ubaedillah dan Abdul

Rozak,2006.Pendidikan

Kewarganegaraan: Demokrasi, Hak Asasi Manusia, dan Masyarakat Madani, Jakarta: ICCE UIN Syarif Hidayatullah .

Soebijanto,FX,1998. "Perencanaan Riset dan Strateginya: Kursus Penyegaran Metode Penelitian Bagi Dosen-Dosen “, Semarang: Undip Press

Soekanto,Soerjono dan Sri Mamudji,2004."Penelitian Hukum Normatif”, Jakarta: Rajawali Press

Winarno,Surachmad,1970. “Dasar dan Tekhnik Research Pengantar Metodologi Ilmiah”, Bandung: CV Tarsito

\section{Peraturan Perundang-Undangan}

UUD Negara Kesatuan Republik Indonesia Tahun 1945

UU Nomor 22 Tahun 1948 tentang Pemerintahan Daerah,

UU Nomor 5 Tahun 1974 tentang PokokPokokPemerintahan di Daerah.

UU nomor 22 Tahun 1999 tentang Pemrintahan Daerah. 
UU nomor 32 tahun 2004 tentang Pemerintahan Daerah.

UU nomor 12 tahun 2008 tentang perubahan Kedua atas UU Nomor 32 Tahun 2004 tentang Pemerintahan Daerah, UU Nomor 1 Tahun 2015

\section{Website}

AA GN Ari Dwipayana, Pilkada Langsung dan Otonomi Daerah, dimuat pada http://www.plod.ugm. ac.id/makalah/pilkadal_dan_otoda.h tm ,diakses 14 Mei 2014.

http://tugasakhirskripsi.blogspot.com/200 9/10/demokrasi-pancasila.html ,diakses 23mei 2015. https://dkelana.wordpress.com/2014/09/14 /untung-rugi-pilkada-langsung-vstidak-langsung/ ,diakses 23 Mei 2015. 